\title{
Climate, nitrogen and grass. II. The influence of light intensity, temperature and nitrogen on vivo digestibility of grass and the prediction of these effects from some chemical procedures ${ }^{1}$
}

\author{
B. Deinum ${ }^{2}$, A. J. H. van Es ${ }^{3}$ and P. J. van Soest ${ }^{4}$ \\ Received 23 July, 1968
}

\section{Summary}

An experiment is described in which the in vivo digestibility was determined of forages grown at different light intensities, temperatures and nitrogen fertilizations. The different factors influenced the chemical composition considerably more than the digestibility. Light intensity had a small positive influence on digestibility and temperature a rather big negative influence, while nitrogen fertilization showed a nonsignificant positive trend. Digestibility was decreased during stem formation.

The samples of the forages were analysed for different compounds enabling the prediction of in vivo digestibility by different procedures of which the in vitro true digestibility appeared to be the most accurate one.

\section{Introduction}

Some research has been done in recent years about the influence of environmental conditions on the chemical composition of herbage (Alberda, 1965; Deinum, 1966a; Deinum and Dirven, 1967), and its (computed) nutritive value (Deinum, 1966b). Light intensity has a positive effect on the water-soluble-carbohydrate content, and a negative one on crude-protein, ash and crude-fibre content resulting in a positive effect on calculated digestibility and starch equivalent. Higher temperature decreases watersoluble-carbohydrate content and increases crude-fibre content causing decreased digestibility and starch equivalent. Nitrogen fertilization increases crude-protein content, but its effect on crude-fibre content is quite variable. In young grass this content is decreased, in old grass it is increased with reversed effects on calculated digestibility and starch equivalent.

However it is not certain whether the calculated digestibilities are identical to the vivo digestibilities. To the best of our knowledge no literature is known about the effect of light intensity and temperature on vivo digestibility of herbage. Fortunately

1 Part of this work was done by the first author at the Animal Husbandry Research Division, A.R.S., Beltsville (Md), U.S.A. on a fellowship of the Netherlands Organisation for the Advancement of Pure Research.

2 Department of Field Crops and Grassland Husbandry, Agricultural University, Wageningen, The Netherlands.

3 Department of Animal Physiology, Agricultural University, Wageningen, The Netherlands.

4 Animal Husbandry Research Division, A.R.S., Beltsville (Md), now at Cornell University, Ithaca (N.Y.), U.S.A. 
there is some information about the effect of nitrogen fertilization on vivo digestibility. Blaser (1964) and Raymond and Spedding (1966) did not find any distinct effect of nitrogen fertilization on vivo digestibility. However, Reid et al. (1967) found a positive effect of nitrogen fertilization on digestibility in tall fescue, but the effect was rather small.

The present study was designed to investigate (1) the influence of light intensity, temperature and nitrogen fertilization on vivo digestibility of herbage and (2) the accuracy of some old and new laboratory procedures with which these effects can be predicted.

\section{Experimental procedures}

\section{Production of the forage}

To measure the above mentioned effects the environmental factors light intensity, temperature and nitrogen fertilization were varied. The two nitrogen treatments were low and high, the nitrogen being given as ammonium-nitrate-limestone. The two light intensities were normal and low light intensity, the latter being established by reducing light intensity to $30 \%$ of normal day light by a cheese-cloth tent of $360 \mathrm{~m}^{2}$. At the low light intensity only the high nitrogen treatment was given. The temperature treatments were established by growing the grass in four different periods of the season. In this way twelve different forages were obtained which varied considerably in chemical composition. All forages were harvested at an age of about four weeks, so the influence of age on digestibility was negligible. Lolium perenne, the most important grass species in the Netherlands was used in all cases, and grown as an almost pure stand on the experimental fields of the Department of Field Crops and Grassland Husbandry. The quantitative description of the environment of the 12 treatments is given in tabel 1 .

The grass was completely vegetative during the periods 1,3 and 4 , while it was generative during period 2 . In that case the percentage stem + leaf sheath was ap-

Table 1 Description of the environmental conditions in the different periods

\begin{tabular}{llrrrrr}
\hline $\begin{array}{l}\text { Treat- } \\
\text { ment }\end{array}$ & \multicolumn{2}{c}{ Period } & $L^{1}$ & $N^{2}$ & \multicolumn{2}{c}{$T^{3}$} \\
\cline { 5 - 6 } & & & & & \\
& & & & & \\
& & & & & \\
1.1 & April 13 - May 10 & 420 & 100 & 13.7 & 2.7 \\
1.2 & April 13 - May 10 & 420 & 25 & 13.7 & 2.7 \\
1.3 & April 13 - May 10 & 126 & 100 & 13.7 & 2.7 \\
2.1 & May 13 - June 9 & 403 & 100 & 18.0 & 9.1 \\
2.2 & May 13 - June 9 & 403 & 40 & 18.0 & 9.1 \\
2.3 & May 13 - June 9 & 121 & 100 & 18.0 & 9.1 \\
3.1 & July 25 - Aug. 32 & 360 & 100 & 21.9 & 12.3 \\
3.2 & July 25 - Aug. 32 & 360 & 25 & 21.9 & 12.3 \\
3.3 & July 25 - Aug. 32 & 108 & 85 & 21.9 & 12.3 \\
4.1 & Sept. 15 - Oct. 17 & 178 & 80 & 17.8 & 10.8 \\
4.2 & Sept. 15 - Oct. 17 & 178 & 25 & 17.8 & 10.8 \\
4.3 & Sept. 15 - Oct. 5 & 72 & 50 & 18.6 & 10.7 \\
& & & & & & \\
\hline
\end{tabular}

$1 \quad \mathrm{~L}=$ average light intensity in cal . $\mathrm{cm}^{-2}$. day-1

$2 \mathrm{~N}=\mathrm{kg} \mathrm{N} / \mathrm{ha}$

s $\quad \mathrm{T}=$ average daily max. and $\mathrm{min}$. temperature 
proximately $60 \%$ at harvest time. As can be seen from table 1 , the treatments 3.3 and 4.3 received smaller quantities of nitrogen than 3.1 and 4.1 , due to the danger of nitrate toxicity at these low light intensities. Treatment 4.3 had to be harvested on October 5 after destruction of the cheese-cloth tent by a gale.

The grass was dried after harvesting at a temperature of about $30^{\circ} \mathrm{C}$ with a large quantity of air in approximately one day, till the dry-matter content was about $90 \%$.

\section{Digestion trials}

These were performed in the Department of Animal Physiology with four wethers. Each of the twelve forages were given to two sheep, either to sheep A and B or to $E$ and $F$. Sheep $E$ and $F$ gave comparable values but sheep $B$ appeared to give lower digestibility values than sheep $A$, the average difference being added to the digestibility of sheep $B$. (This is justified by the fact that sheep $A, E$ and $F$ showed the same regression line between in vivo apparent digestibility and in vitro true digestibility while sheep B was off this line. In other trials where the same diets were fed to sheep $A$ and $E$ or to $B$ and $F$, sheep B also showed lower digestibility.) The animals received a daily amount of 800 grams air dry grass +3 grams minerals during the 10-day's preliminary period and the 7-day's total collection period.

\section{Chemical analysis}

The grass samples were analysed for dry matter, nitrate $\left(\mathrm{NO}_{3}\right)$, crude protein (cp), ash, water-soluble carbohydrate (wsc), crude fibre (cf), cell wall (cwc), acid-detergent fibre (adf), lignin (l) and in vitro true digestibility $\left(D_{\text {vitro true }}\right)$. The faeces samples were analysed for dry matter, crude protein, ash, cell wall, acid-detergent fibre and lignin. The cell-wall, acid-detergent-fibre, lignin and $\mathbf{D}_{\text {vitro true }}$ determinations were carried out according to Van Soest et al. (1967, 1963, 1968 and 1966 respectively) by the first author in the laboratory of the Animal Husbandry Research Division, Agricultural Research Service, Beltsville (Md), U.S.A.

\section{Results and discussion}

\section{Influence of environmental conditions on the chemical composition and} digestibility of herbage

The chemical composition and the digestibility of the twelve herbages is mentioned in table 2. As can be seen from this table, the twelve forages had quite different chemical compositions which were due to the various environments during growth. However the measured digestibilities did not vary that much, while the average value was very high (average dry matter digestibility $=77.5$; average organic matter digestibility $=80.5$ ). This shows once more that perennial ryegrass has a very good quality under normal Dutch conditions.

The effects of light intensity, temperature and nitrogen fertilization on chemical composition and digestibility of the forages are calculated by multiple regression analysis (table 3). Their effects on nitrate, crude-protein, ash, water-soluble-carbohydrate and crude-fibre content are in fair agreement with those mentioned by Deinum (1966a); the effect of temperature on crude-fibre content being fairly low however. The effects on cell-wall, acid-detergent-fibre and lignin content are comparable to those on the crude-fibre content (a part of the cell walls as well), although many regression coefficients did not reach significance. Light intensity and nitrogen fertilization show a 
Table 2 Chemical composition (in \% of $\mathrm{dm}$ ) and digestibility of the twelve forages

\begin{tabular}{|c|c|c|c|c|c|c|c|c|c|c|c|c|}
\hline $\begin{array}{l}\text { Treat } \\
\text { ment }\end{array}$ & $\mathrm{NO}_{3}$ & $c p$ & $a s h$ & $w s c$ & $c f$ & $c w c$ & $a d f$ & $l$ & $D_{\mathrm{dm}}$ & $D_{\text {om }}$ & $D_{\mathrm{cp}}$ & $D_{\text {vitro truc }}$ \\
\hline 1.1 & 0.20 & 21.1 & 8.5 & 15.7 & 20.8 & 45.0 & 23.8 & 1.54 & 83.8 & 85.6 & 82.0 & 94.0 \\
\hline 1.2 & 0.04 & 13.4 & 7.2 & 30.8 & 18.3 & 39.5 & 19.9 & 1.81 & 84.6 & 86.8 & 73.5 & 95.5 \\
\hline 1.3 & 0.40 & 24.3 & 9.7 & 9.5 & 23.0 & 46.1 & 24.7 & 2.07 & 84.5 & 86.5 & 84.0 & 93.9 \\
\hline 2.1 & 0.27 & 16.3 & 9.0 & 9.0 & 29.2 & 55.4 & 33.4 & 3.20 & 75.2 & 76.4 & 75.0 & 88.9 \\
\hline 2.2 & 0.02 & 10.7 & 8.8 & 13.7 & 29.3 & 56.4 & 33.7 & 4.13 & 74.2 & 75.8 & 69.0 & 87.9 \\
\hline 2.3 & 1.25 & 19.2 & 10.9 & 5.9 & 29.9 & 53.6 & 33.7 & 3.92 & 72.0 & 73.3 & 79.7 & 86.7 \\
\hline 3.1 & 0.64 & 24.7 & 9.9 & 11.3 & 21.5 & 43.3 & 23.4 & 1.91 & 78.6 & 82.7 & 84.7 & 92.3 \\
\hline 3.2 & 0.09 & 19.2 & 10.9 & 12.7 & 22.1 & 45.0 & 25.7 & 2.81 & 78.4 & 82.1 & 79.8 & 91.3 \\
\hline 3.3 & 1.89 & 25.1 & 12.5 & 3.5 & 26.0 & 49.0 & 27.8 & 2.37 & 73.6 & 77.9 & 81.1 & 91.0 \\
\hline 4.1 & 1.60 & 23.5 & 11.8 & 6.6 & 26.1 & 47.5 & 29.0 & 2.94 & 76.3 & 80.4 & 81.0 & 90.7 \\
\hline 4.2 & 0.09 & 18.6 & 11.7 & 8.2 & 25.9 & 49.7 & 29.4 & 2.56 & 75.0 & 79.3 & 79.3 & 89.6 \\
\hline 4.3 & 2.28 & 26.2 & 14.0 & 2.7 & 25.0 & 46.7 & 28.3 & 3.09 & 75.0 & 79.2 & 82.6 & 89.5 \\
\hline
\end{tabular}

negative, temperature and stage of growth a positive influence on these concentrations.

The influence of light intensity and nitrogen fertilization on digestibility is positive but rather small, while the influence of temperature and stage of growth is negative, but fairly big. However, the effect of nitrogen is not significant. These effects are opposite to those on the cell wall fractions which is not surprising, because the cell walls are the less digestible parts of the plant.

Table 3 Effect of environment on chemical composition and digestibility calculated by multiple regression analysis

\begin{tabular}{|c|c|c|c|c|c|c|c|}
\hline Compound & Light ${ }^{1}$ & Temp. ${ }^{1}$ & $N_{1}$ & Stage 1 & Constant & $R^{2}$ & R.S.D. \\
\hline $\mathrm{NO}_{3}$ & $-0.37 *$ & 0.064 & 0.52 & -0.16 & 0.69 & 0.66 & 0.59 \\
\hline $\mathrm{cp}$ & $-1.26 * \ldots$ & $0.37 *$ & $8.22 * *$ & $-6.89 * * * *$ & 21.60 & 0.94 & 1.49 \\
\hline ash & $-0.95^{* *}$ & $0.26^{* *}$ & -0.47 & -0.56 & 10.40 & 0.89 & 0.79 \\
\hline wsc & $3.21 * * *$ & $-1.02 \%$ & -6.81 & -2.33 & 23.60 & 0.84 & 3.78 \\
\hline cf & $-1.16^{*}$ & 0.26 & -0.11 & $6.92^{* \%}$ & 15.75 & 0.89 & 1.54 \\
\hline cwc & -0.91 & 0.24 & -0.26 & $9.90 *$ & 35.01 & 0.81 & 2.68 \\
\hline adf & $-1.16^{*}$ & 0.31 & -1.03 & $8.58 \%$ & 16.57 & 0.86 & 2.07 \\
\hline 1 & $-0.21 *$ & $0.05 *$ & -0.08 & $1.64 * *$ & 1.08 & 0.90 & 0.32 \\
\hline $\mathrm{D}_{\mathrm{dm}}$ & $1.26 *$ & $-0.80^{* * *}$ & 1.75 & $-5.87 * *$ & 91.0 & 0.92 & 1.60 \\
\hline$D_{\text {om }}$ & $1.10^{*}$ & $-0.57 *$ & 1.23 & $-7.76 * \cdots$ & 94.1 & 0.94 & 1.40 \\
\hline D calc. (Dijkstra) & $1.77 \%$ & -0.40 & 0.30 & $-8.33^{* * *}$ & 87.5 & 0.89 & 1.95 \\
\hline D vitro app. (Van Socst) & $1.20^{*}$ & $-0.51 * *$ & 2.07 & -7.57 * & 89.4 & 0.92 & 1.54 \\
\hline$D_{\text {summ.cqua. (Van Soest) }}$ & 0.65 & -0.25 & 1.62 & $-7.93 *$ & 88.3 & 0.65 & 3.36 \\
\hline
\end{tabular}

1 effect of light intensity per $100 \mathrm{cal} . \mathrm{cm}^{-2}$. day-1;

effect of temperature per ${ }^{\circ} \mathrm{C}$ (24 hours average);

effect of nitrogen per $100 \mathrm{~kg} \mathrm{~N} / \mathrm{ha} /$ period;

Vegetative stage $=1 ;$ shooting stage $=2$

$\mathrm{R}=$ correlation coefficient

R.S.D. $\doteq$ Residual Standard Deviation

* Significant at $5 \% ; \%$ significant at $1 \% ; \quad * * *$ significant at $0.1 \%$ level 
It can be calculated from these results that the approximately 10 units lower digestibility of the forage in late spring compared to early spring is caused by both increased temperature and stem formation, and that the vegetative grass in high summertime will have an approximately 7 units lower digestibility than in early spring due to the higher temperatures. The about 2 units lower digestibility of autumn grass compared to summer grass may be due to the low light intensity and the still comparatively high temperature in this part of the season.

These results may indicate too that digestibility of forages in warm areas like the tropics can be rather low.

The crude-protein content and its digestibility were affected in the same way by the environmental conditions. As expected, the data fitted so well in the formula of Dijkstra (1966): dcp $=0.96 \mathrm{cp}-4.01$, that no specific effect of environment on crude-protein digestibility could be detected.

\section{Prediction of in vivo digestibility from different laboratory procedures}

After this description of the effect of environment on vivo digestibility it is interesting to see whether these effects can be calculated with the aid of laboratory procedures as well. Three different procedures have been used: the crude-fibre system of Dijkstra and the two systems of Van Soest, a biological one and a chemical one. These twelve forages have been part of a group of more than 100 samples of known digestibility which were used for a more general research into the accuracy with which vivo digestibility can be predicted with the aid of these procedures (Deinum and Van Soest, in preparation.)

In the first system the equation of Dijkstra (1954) was used which was derived from data on herbage from all kinds of grasslands:

$D_{\text {on }}=-1.60 \mathbf{c f}_{\text {om }}+120.0$

The average difference between vivo and calculated organic matter digestibility was $+3.88 \pm 0.50$ which shows that the digestibility of our perennial ryegrass forages was clearly underestimated by the crude-fibre method (figure 1a). This may be caused
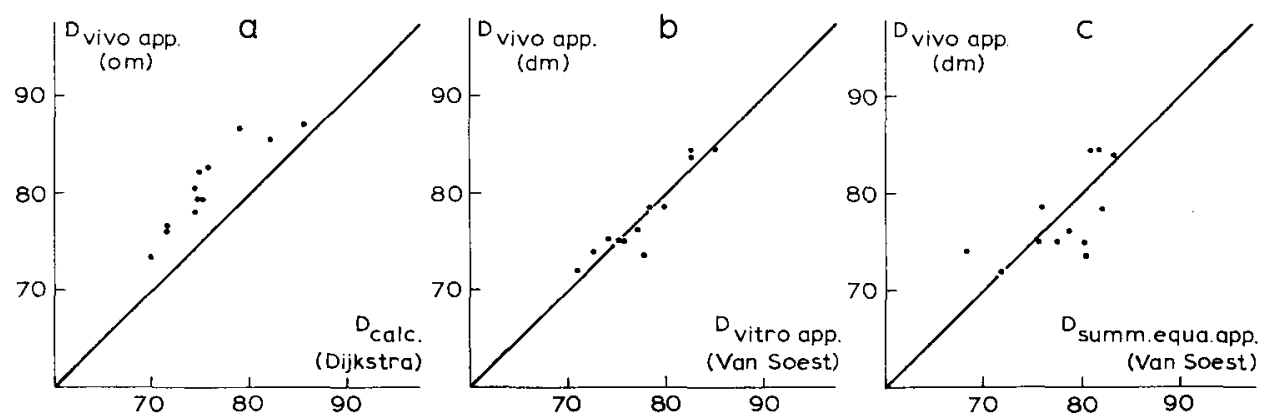

Fig. I Relationship between vivo and calculated digestibility:

a. apparent vivo digestibility of organic matter versus calculated digesfibility of organic matter according to Dijkstra (1954);

b. apparent vivo digestibility of dry matter versus apparent vitro digestibility of dry matter according to Van Soest et al. (1966);

c. apparent vivo digestibility of dry matter versus apparent digestibility calculated with the summative equation of Van Soest et al. (1968). 
by its very low lignin content (lignin usually provides more information about digestibility than crude-fibre does). If this difference would not have existed the line $D_{\text {vivo }}=D_{\text {calculated }}$ would have given a residual standard deviation of 1.79 .

Using this system the effect of environment on digestibility can be calculated again (see Table 3 ). In the case of highly reliable results the regression coefficients of light intensity, temperature, nitrogen fertilization and stage of growth should be the same for $D_{\text {om vivo }}$ and $D_{\text {calc.Dikstra. }}$. Comparison of these coefficients shows that the effect of light intensity is overestimated by the crude-fibre system while the effect of temperature is underestimated somewhat, however the differences not being significant.

In the second system the in vitro procedure of Van Soest is used which provides the true digestibility. The difference between true and apparent digestibility is considered as being the excretion of bacterial cell walls and of endogenous substances. This excretion was linearly related to true digestibility in this experiment with its narrow range of high quality forages, whereas it seems to be a curvilinear relationship in a much wider range of digestibilities (Deinum and Van Soest, in preparation). The endogenous excretion was in these forages:

End. excretion $=69.7-0.62 \mathrm{D}_{\text {vitro true }}$ giving:

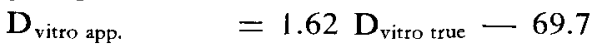

The average difference between vivo and vitro apparent digestibility was then zero, whereas the residual standard deviation of the equation $D_{\text {vivo app. }}=D_{\text {vitto app. }}$ was 1.73 which is rather low (figure $1 \mathrm{~b}$ ).

Comparison of the influence of environment on apparent digestibility in vivo and in vitro (Table 3) shows that the influence of light intensity is the same in both cases whereas the effect of temperature is underestimated somewhat. Again this difference is not significant.

The third procedure used is the calculation of digestibility with the summative equation developed by Van Soest et al. (1965 and 1968):

$\mathrm{D}_{\text {summ.equa.true }}=0.98(100-\mathrm{cwc})+\mathrm{cwc}\{1.81-0.97 \log (1 \times 100 / \mathrm{adf})\}$ and

$D_{\text {summ.equa.app. }}=D_{\text {summ.equa.true }}-$ End. excr.

In this case the above mentioned equation for the endogenous excretion was used. With this procedure the average difference between vivo and calculated apparent digestibility was -0.3 , but the residual standard deviation of the equation $\mathrm{D}_{\text {vivo app. }}=$ $\mathrm{D}_{\text {calc.app. }}$ was rather high, viz. 4.06 (figure 1c). This deviation is even higher than is found in the group of more than 100 samples mentioned before. This poor result is possibly caused by the very low lignin content in these high quality forages which is difficult to measure with high precision at these low concentrations. These poor results may also be the cause of the lack of significance of the influence of environment on calculated digestibility, whereas the regression coefficients did not agree either with those on vivo digestibility (Table 3 ). Studies for further improvement of the system of the summative equation are underway.

Summarizing these results it is clear that of the laboratory techniques tested the in vitro procedure gave the best estimate both of the vivo digestibility and of the effect of environment on vivo digestibility. 


\section{Acknowledgement}

The authors want to express their gratitude for the skillful assistance of Mr. K. van der Laan who collected the forages, Mr. J. E. Vogt and Mr. R. Terluin who conducted the digestion trials and of Mr. H. K. Goering, Beltsville who cooperated in the chemical analysis.

\section{References}

Alberda, Th., 1965. The influcene of temperature, light intensity and nitrate concentration on drymatter production and chemical composition of Lolium perenne L. Neth. J. Agric. Sci., 13: 335-360.

Blaser, R. E., 1964. Symposium on forage utilization. Effects of fertility levels and stage of maturity on forage nutritive value. J. anim. Sci., $23: 246-253$.

Deinum, B., 1966a. Climate, nitrogen and grass. I. Research into the influence of light intensity, temperature, water supply and nitrogen on the production and chemical composition of grass. Meded. Landbouwhogeschool, Wageningen, 66-11: 1-91.

Deinum, B., 1966b. Influence of some climatological factors on the chemical composition and feeding value of herbage. Proc. 10th Intern. Grassld Congr., Helsinki : 415-418.

Deinum, B. and Dirven, J. G. P., 1967. Informative experiment on the influence of light intensity and temperature on dry-matter production and chemical composition of Brachiaria ruziziensis Germain and Everard. Surin. Landb., $15: 5-10$.

Dijkstra, N. D., 1954. What has the State Agricultural Experiment Station at Hoorn contributed to research into the feeding value of roughages? Neth. J. Agric. Sci., 2: 273-297.

Dijkstra, N. D., 1966. Estimation of the nutritive value of fresh forages. Proc. 10th Intern. Grassld Congr., Helsinki : 393-397.

Raymond, W. F. and Spedding, C. R. W., 1966. Nitrogenious fertilizers and the feed value of grass. In : Nitrogen and Grassland. Proc. 1st General Meeting Eur. Grassland Fed. : 151-160.

Reid, R. L., Odhuba, E. K. and Jung, G. A., 1967. Evaluation of tall fescue pasture under different fertilizer treatments, Agron. J., $59: 265-271$.

Van Soest, P. J., 1963. Use of detergents in the analysis of fibrous feeds. II. A rapid method for the determination of fibre and lignin. J. Assoc. Off. Anal. Chem., 46: 829-835.

Van Soest, P. J. and Moore, L. A., 1965. New chemical methods for analysis of forages for the purpose of predicting nutritive value. Proc. 9th Intern. Grassld Congr., Sao Paulo: 785-789.

Van Soest, P. J., Wine, R. H. and Moore, L. A., 1966. Estimation of the true digestibility of forages by the in vitro digestion of cell walls. Proc. 10th Intern. Grassld Congr., Helsinki : $438-441$.

Van Soest, P. J. and Wine, R. H., 1967. Use of detergents in the analysis of fibrous feeds. IV. Determination of plant cell-wall constituents. J. Assoc. Off. Anal. Chem., 50: 50-55.

Van Soest, P. J. and Wine, R. H., 1968. The determination of lignin and cellulose in acid-detergent fibre with permanganate. J. Assoc. Off. Anal. Chem., 51 (in press). 